\title{
Free of salt high-pressure deliming of animal hides
}

\author{
Michael Prokein ${ }^{1} \cdot$ Adrian Chrobot $^{1} \cdot$ Manfred Renner $^{1} \cdot$ Eckhard Weidner $^{1,2}$
}

Received: 3 April 2020 / Accepted: 15 June 2020 / Published online: 27 June 2020

(C) The Author(s) 2020

\begin{abstract}
The wastewater pollution of tanneries is of high concern. The investigation of technologies to minimize the consumption of chemicals in the leather production process can reduce the environmental burden. We focus on the reduction of ammonium salts in the leather production process. Salt-free deliming of animal hides with compressed carbon dioxide as deliming agent is performed for the first time in a technical scale 20 - $\mathrm{L}$ drum. As a result, $\mathrm{CO}_{2}$-deliming at 30 bar and $30{ }^{\circ} \mathrm{C}$ is two times faster than conventional deliming. In addition, the deliming efficiency is slightly improved. The initial calcium $(\mathrm{Ca})$ content of the hides of $8 \mathrm{~g} / \mathrm{kg}$ reaches the lowest value of $2 \mathrm{~g} / \mathrm{kg}$ after a process time of $3 \mathrm{~h}$. However, a process time of $60 \mathrm{~min}$ is sufficient to reach an elimination of $50 \mathrm{wt} \%$ of the initial lime. The resulting Ca-content of $4 \mathrm{~g} / \mathrm{kg}$ after $60 \mathrm{~min} \mathrm{CO}_{2}$-deliming at 30 bar is comparable with the Ca-content of conventional delimed hide. We clarify that the ampholytic character of the collagen itself enables a buffering of the $\mathrm{pH}$-value at $\mathrm{pH}-7$. The stable $\mathrm{pH}$-value supports the selection of specific bating enzymes that decompose noncollagen proteins. No buffering salts contaminate the wastewater. The high-pressure $\mathrm{CO}_{2}$-deliming process has high potential to reduce wastewater emissions, save costs for chemicals, and process time in industrial beamhouse applications.
\end{abstract}

Keywords High-pressure $\cdot \mathrm{CO}_{2} \cdot$ Leather $\cdot$ Deliming $\cdot$ Ammonium nitrogen emissions

\section{Introduction}

The production from raw animal hide to leather goods consists of 4 main categories: beamhouse, tanning, wet end, finishing. Each category includes a variety of working steps consuming high amounts of water and process chemicals (Joseph and Nithya 2009).

In the beamhouse, raw hide is prepared for the tanning process by soaking, liming, unhairing, deliming, bating, and pickling. During the preparation, hairs are removed and the hide is modified in chemical containing aqueous solutions, called floats. All chemicals used in the beamhouse are lost with the wastewater (Buljan et al. 2000, Black et al. 2013). As a result, beamhouse processing causes environmental challenges in developing countries and/or enormous costs in

Responsible Editor: Philippe Garrigues

Michael Prokein

michael.prokein@umsicht.fraunhofer.de

1 Material Systems and High-pressure Technology, Fraunhofer Institute UMSICHT, Osterfelder Str. 3, 46047 Oberhausen, Germany

2 Chair of Process Technology, Ruhr University, Universitätsstr. 150, 44780 Bochum, Germany modern tanneries. According to estimations, the costs of environmental protection measures in European tanneries account for $4.3 \%$ of their turnover while their profit margin is just about 5\% (Cotance 2012).

The use of dense carbon dioxide promises a high potential to reduce the environmental burden caused by the leather production process as already reviewed and highlighted by several authors (Sathish et al. 2016; Hu and Deng 2016; Renner et al. 2009; Renner et al. 2012). Recently, we demonstrated a $\mathrm{CO}_{2}$-intensified low-emission tanning process to produce high-quality leather in a $1700-\mathrm{L}$ drum at 30 bar (Prokein et al. 2017). Supplementary to our previous work, we investigate the application of process features of the $\mathrm{CO}_{2}$-tanning process to the deliming process. The aim is a low-emission, accelerated lime removal from the hide by substituting conventional ammonium salts with dense carbon dioxide as deliming agent to prepare the hides for the $\mathrm{CO}_{2}$-intensified tanning process.

\section{Collagen}

Animal hide consists of three merging layers: epidermis, dermis, subcutis. For the leather production, only collagen of the 
dermis is used. The other parts of the hide are utilized in other industries or have to be disposed of (Onem et al. 2018).

Collagen is with between 40 and $70 \mathrm{wt} \%$ of dry matter, the predominant proportion in the finished leather. As a protein, collagen is reactive towards tannins, dyestuffs, and other leather chemicals because of numerous peptide groups and its content of functional carboxy and amino groups (Reich and Taeger 2009).

Collagen is a polyampholyte with basic and acidic amino acids that can have negative and positive charges depending on the $\mathrm{pH}$-value. The different charges influence the hide properties as reactivity against leather chemicals, water absorption capacity, and the orientation of the collagen fibrils. The water absorption capacity and the orientation affect the tenseness and mass transport through the cross-section of the hide, dramatically (Paul and Bailey 2003). For example, strong acid swelling at $\mathrm{pH}-3$ leads to a very slow mass transport and a high degree of tenseness that irreversibly damages the collagen fibers. The high tenseness results in a decrease in strength and low leather qualities (Faber and Herfeld 1990). Therefore, proper control of the $\mathrm{pH}$-value is essential in leather manufacturing to produce high-quality leather (Paul and Bailey 2003; Moog 2016).

The relation between the $\mathrm{pH}$-value, the water absorption capacity, and tenseness is discussed in the " $\mathrm{CO}_{2}$-deliming in a $20-\mathrm{L}$ autoclave at 30 bar" section in detail.

\section{Conventional deliming}

Before the deliming process starts, hide is chemically unhaired at $\mathrm{pH}-12.5$ in a sulfide- and lime-containing float. After unhairing, the hide contains calcium, which weakly bonds to the collagen, and sulfides that have to be removed (Lofrano et al. 2013).

At the high $\mathrm{pH}$-value of 12.5 , the unhaired hide is anionic and swollen and shows a low compressibility. The swollen fiber structure impedes chemicals and water to penetrate through the collagen structure. In this condition, excising the lime from the hide is not possible (Heidemann 1993).

The removal of the calcium is achieved by decreasing the $\mathrm{pH}-\mathrm{value}$ with acidic chemicals. By acidifying the collagen at $\mathrm{pH}-12.5$, the amino groups are protonated. Thereby, positive charges neutralize the negative charged collagen and the fiber structure opens facilitating chemicals to penetrate. In conventional deliming, ammonium salts are preferred for this application because they enable comparable short process times and buffer the $\mathrm{pH}$ at around 9. When the $\mathrm{pH}$-value is not stable, the selection of convenient bating enzymes for the following working step is not possible (Covington 2009).

From an environmental point of view, ammonium salts have many disadvantages. The salts cause the formation of ammonium nitrogen $\left(\mathrm{NH}_{3}-\mathrm{N}\right)$ that is one of the key pollutants in the leather production process. About $6 \mathrm{~kg}$ of $\mathrm{NH}_{3}-\mathrm{N}$ originates when 1 ton raw hide is processed to leather with conventional deliming. Approximately $80 \%$ of the total $\mathrm{NH}_{3}$ $\mathrm{N}$ emission results from conventional ammonium salt deliming (Buljan 2000; Wang et al. 2012). $\mathrm{NH}_{3}-\mathrm{N}$ can form ammonia gas $\left(\mathrm{NH}_{3}\right)$ causing serious diseases in contact with human beings. $\mathrm{NH}_{3}-\mathrm{N}$ exists also in aqueous solutions and leads to various environmental pollutions summarized by Deng et al. (2015).

\section{$\mathrm{CO}_{2}$-deliming}

$\mathrm{CO}_{2}$-deliming is an alternative to conventional ammonium salt deliming. The mechanism of $\mathrm{CO}_{2}$-deliming is simple. By dissolving carbon dioxide in water, it partly converts to carbonic acid. The carbonic acid species acidify the float and remove calcium (Meregallo and Becalli 1990; Guttenberg 1994).

In contrast to the simple theoretical mechanism, the use of $\mathrm{CO}_{2}$ for deliming at ambient conditions has several challenges. First, the solubility of carbon dioxide in water is low leading to unacceptable operating times compared with conventional ammonium deliming. The solubility increases at cold conditions. However, enzymes needed for the following bating process show their optimal activity between 30 and 40 ${ }^{\circ} \mathrm{C}$. In addition, the penetration of the dissolved carbon dioxide through the cross-section of the hide is slow which impedes treating thick hides. In addition, controlling the amount of available gas to keep the $\mathrm{pH}$-value stable without using buffering salts is not applicable (Deng et al. 2015; Covington 2009; Flowers 2002).

Due to the challenges, $\mathrm{CO}_{2}$-deliming is industrially only performed in combination with ammonium salts. Thereby, about $75 \%$ of $\mathrm{NH}_{3}-\mathrm{N}$ emission caused by conventional deliming can be avoided; however, 25\% remain (Black et al. 2013).

\section{Research issue}

The most important challenge preventing salt-free $\mathrm{CO}_{2}$ deliming is the low solubility of $\mathrm{CO}_{2}$ in water at ambient conditions (" $\mathrm{CO}_{2}$-deliming" section). An opportunity to overcome this challenge at applicable temperatures $\left(30\right.$ to $\left.40{ }^{\circ} \mathrm{C}\right)$ is to increase the pressure. For example, the solubility of $\mathrm{CO}_{2}$ in water at a temperature of $30^{\circ} \mathrm{C}$ and a pressure of 50 bar is with $47.5 \mathrm{~g} / 1$ approximately 40 times higher compared with a $\mathrm{CO}_{2}-$ partial pressure of 1 bar (Duan and Sun 2003). Due to the pressure-induced solubility and the carbonic acid formation, the $\mathrm{pH}$-value of water decreases to about 3 above a pressure of 30 bar (Peng et al. 2013; Mohamed et al. 2011). Figure 1 shows the pH-curve of $\mathrm{CO}_{2}$-saturated water at $32{ }^{\circ} \mathrm{C}$ according to Meyssami et al. (1992). 


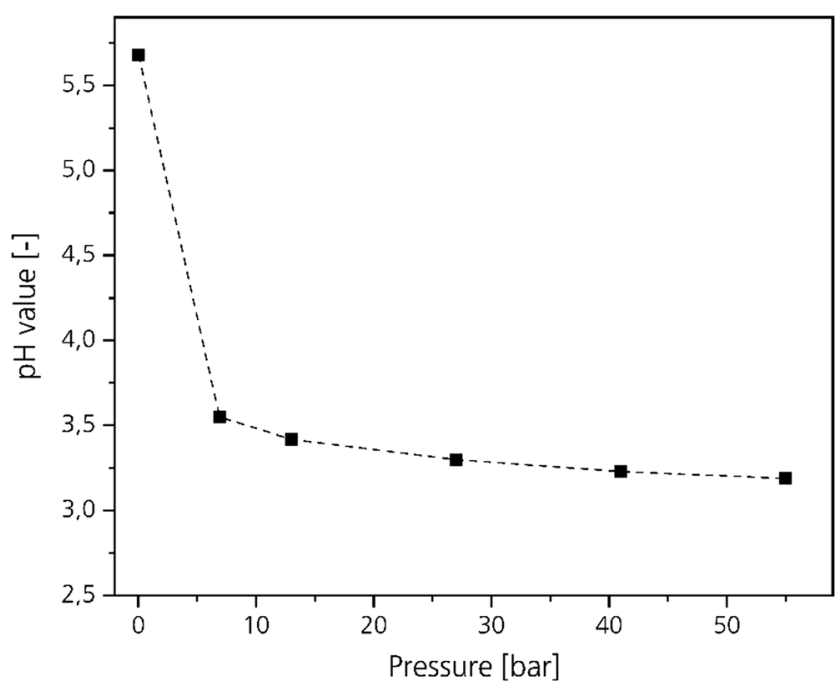

Fig. 1 pH-value of water saturated by $\mathrm{CO}_{2}$ depending on the $\mathrm{CO}_{2}$ partial pressure at $32{ }^{\circ} \mathrm{C}$ (Meyssami et al. 1992)

A reduction of the collagens' $\mathrm{pH}$-value to $\mathrm{pH}-3$ at $30 \mathrm{bar}$ would cause acid swelling and irreversibly damage the hide structure ("Collagen" section). However, the solubility of $\mathrm{CO}_{2}$ in water and thereby the effect on the $\mathrm{pH}$-value can be influenced by various chemicals or materials (Chuang and Johannsen 2009). Since collagen is a polyampholyte with an enormous binding capacity for acids, we assume that the $\mathrm{pH}$ value in a $\mathrm{CO}_{2}$ pressurized system shows a different trend in a collagen-containing float compared with pure water. Since the design of conventional tanning equipment is only convenient for ambient conditions, high-pressure deliming and the effect of pressurized $\mathrm{CO}_{2}$ on the $\mathrm{pH}$ of water containing unhaired hide at $\mathrm{pH}-12.5$ has not been investigated, yet.

Beyond deliming, several authors considered the application of dense carbon dioxide in various working steps of the leather production process. However, nearly all of the work focused on lab scale experiments with supercritical $\mathrm{CO}_{2}$ linked to pressures above 74 bar ( $\mathrm{Hu}$ and Deng 2016; Sathish et al. 2016). To build equipment that is able to operate with supercritical $\mathrm{CO}_{2}$ for industrial beamhouse applications is challenging. The main problem is the needed diameter for the high-pressure equipment to be able to process up to $12 \mathrm{t}$ of hide in a volume of more than $20 \mathrm{~m}^{3}$ per batch comparable with conventional beamhouse operations (Renner 2015).

The $\mathrm{CO}_{2}$-intensified tanning process developed by Renner et al. is the only workstep in the leather production chain that was demonstrated in pilot scale (500 kg full bovine hide tanning). The reason for this is the moderate operating pressure of 30 bar, which enables the development of high-pressure rotating drums for industrial applications. The process combines the positive characteristics of the conventional chromium tanning process like high performance and quality with the possibility of saving process time, chromium tanning agent, and water, especially wastewater. The process is commercially attractive as the return on investment is less than 2 years (Weidner 2018) (Prokein et al. 2017) (Renner et al. 2012) (Renner et al. 2009).

Derived from the state of research, the aim of this work is to adapt features of the $\mathrm{CO}_{2}$-intensified tanning process to the deliming process. The challenges of the conventional $\mathrm{CO}_{2}$ deliming process caused by low solubility of $\mathrm{CO}_{2}$ at ambient conditions should be overcome by deliming at 30 bar. The influences of the evaluated pressure on the $\mathrm{pH}$-value including linked changes of collagen properties and the lime removal efficiency are considered.

\section{Materials and methods}

\section{High-pressure equipment}

\section{High-pressure view cell}

The influence of pressurized $\mathrm{CO}_{2}$ on the $\mathrm{pH}$-value of pure water and floats containing collagen were carried out in a high-pressure view cell. Figure 2 shows a schematic diagram and a photograph of the equipment. The cell has a volume of $63 \mathrm{~mL}$, a maximum pressure of $300 \mathrm{bar}$, and a maximum operation temperature of $260^{\circ} \mathrm{C}$.

To pressurize the cell, a high-pressure pump compresses $\mathrm{CO}_{2}$ that is stored at 60 bar in a $\mathrm{CO}_{2}$ tank. By opening valve 3 , the cell can be manually pressurized to the desired pressure. Valve 4 enables the depressurization.

A sapphire window positioned at the front of the view cell enables the observation of the process. A lamp installed behind a second rear window lights up the interior of the cell. A stirrer can optionally improve the mass transport.

\section{Twenty liter high-pressure drum}

Deliming test series were carried out in PLC-controlled 20-L high-pressure equipment. Figure 3 shows a schematic diagram and a photograph of the apparatus. A rotatable basket is installed inside a horizontal, cylindrical vessel. In the rotating basket, hides are processed comparable with industrial procedures. Pikes inside the basket ensure that the hides move around continuously during deliming.

$\mathrm{CO}_{2}$ is stored in a $\mathrm{CO}_{2}$ tank at 60 bar. A high-pressure pump (P1) allows pressurization of the reactor with pressures between 30 and 280 bar. A second pump (P2) allows the pumping of liquids against the maximum pressure of the reactor. Liquids are stored in a separate reservoir. At the end of the process, the reactor is depressurized and the $\mathrm{CO}_{2}$ is separated from the liquids. 

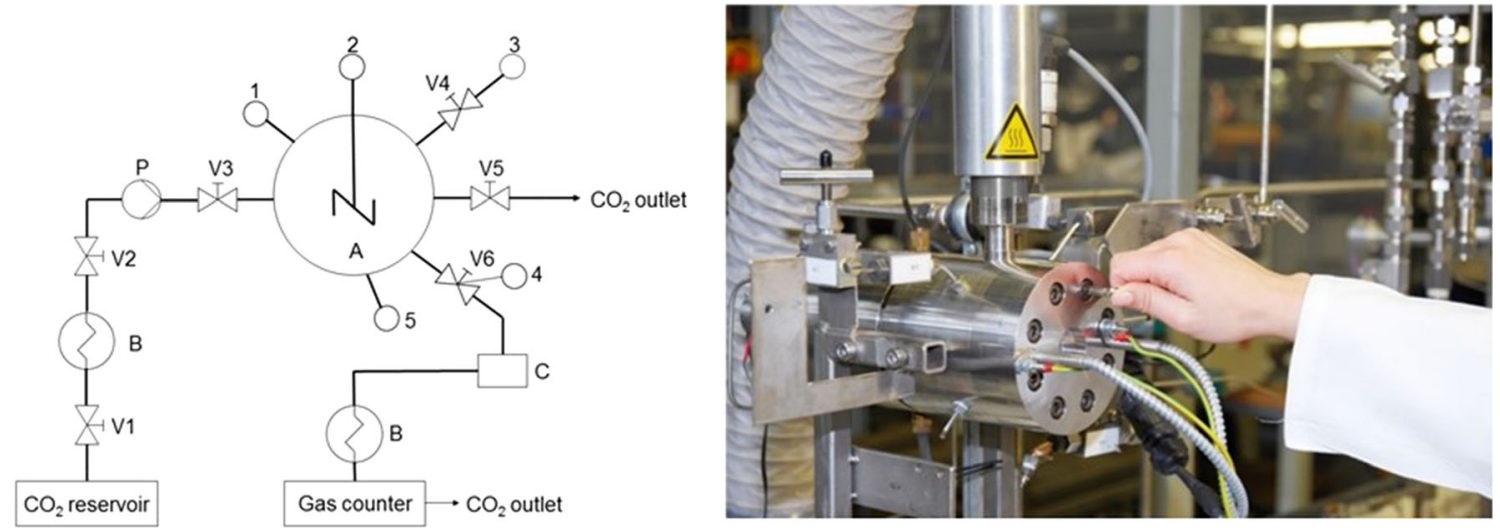

Fig. 2 Schematic diagram and a photograph of the 63-ml high-pressure view cell; A, cell; B, heat exchanger; C, separator; P, pump; V, valve; 1, pressure sensor; 2 , stirrer; 3 , inlet for liquids; 4 , temperature sensor; 5 , temperature control

\section{Hide}

Bull hide with a surface area of approximately $7 \mathrm{~m}^{2}$ and a wet weight of about $25 \mathrm{~kg}$ was used. Conventional unhaired hides at $\mathrm{pH}-12.5$ and conventional delimed hides at $\mathrm{pH}-8.5$ were provided by »Lederfabrik Josef Heinen GmbH \& Co. KG«. The split was $4.5 \mathrm{~mm}$. The unhaired hides were used for the high-pressure deliming test series. The conventional delimed hides were used as reference.

As already described in previous work, a bovine hide is divided into several parts with different characteristics and fiber structure (Prokein et al. 2017). The parts can be defined in terms of butt, belly, and neck. The part with the highest quality and the most regular structure is the butt, called croupon.

For each experiment in the 20-L equipment, 10 hide samples with a size of $15 \mathrm{~cm} \times 20 \mathrm{~cm}$ each, were cut out of the croupon. The average weight of the samples was $199.4 \mathrm{~g}$ with a standard deviation of 14.7. For the trials in the view cell, smaller cylindrical samples of some grams were punched out of the croupon.

\section{Analytics}

Hide is a material characterized by natural deviations. To minimize the influence of the deviations, all 10 hide samples of each 20-L trial were considered for the analytics apart from the residual calcium and sulfide determinations described in the "Lime- and sulfide-contents of hide and float" section. In addition, we performed double determinations for each experiment. From all results, average values including standard deviations were determined. As reference, the conventional delimed hides were equally analyzed to assess the tenseness and compressibility ("Tenseness and compressibility" section) and lime- and sulfide-contents ("Lime- and sulfide-contents of hide and float" section).

\section{Hide weight and thickness}

The weight and the thickness of the hides before and after $\mathrm{CO}_{2}$-deliming indicate whether the charges of the collagen and thereby the fiber structure and water absorption capacity changed. Therefore, the weights and the thicknesses of all
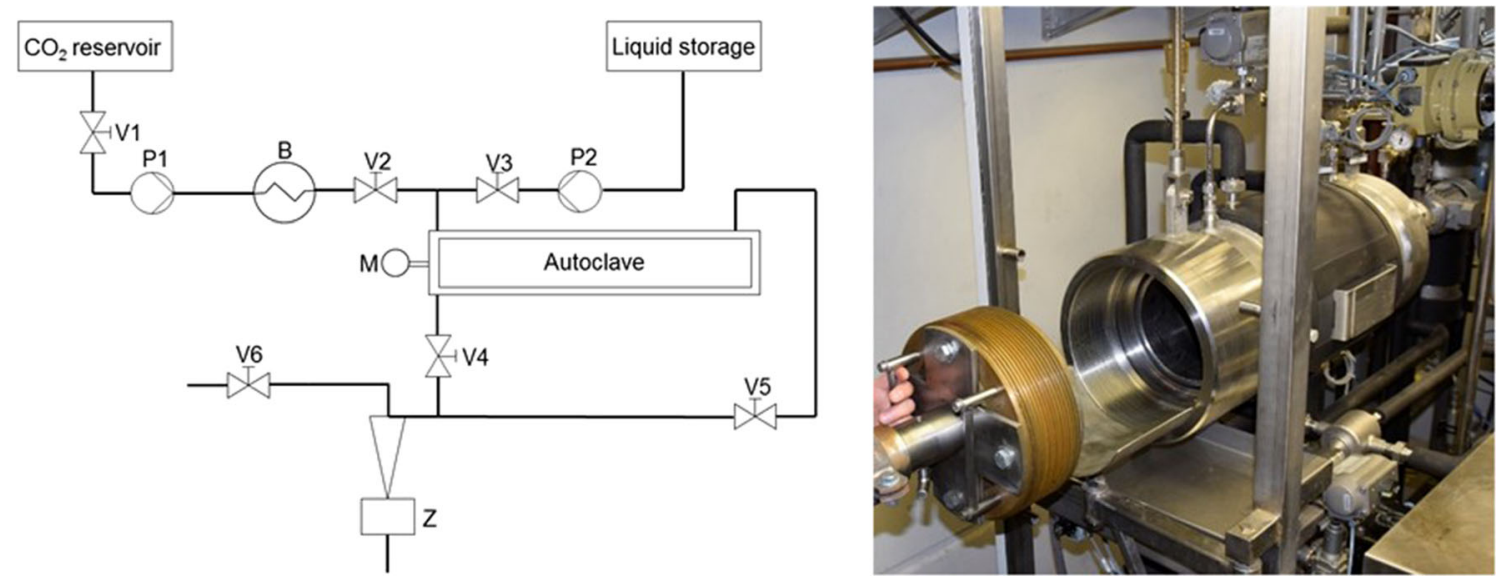

Fig. 3 Schematic diagram and photo of the 20-L autoclave; B, heat exchanger; P, pump, M, motor; Z, cyclone; V, valve 
samples were measured before and after the high-pressure $\mathrm{CO}_{2}$-deliming process.

The thickness of each sample was determined by considering 4 marked areas per sample before and after deliming to calculate an average value including standard deviation.

\section{Tenseness and compressibility}

The change in tenseness and compressibility of the hides due to $\mathrm{CO}_{2}$-deliming is determined by a principle of Herfeld and Schubert. A cylindrical specimen is placed on a defined area of a hide sample. The ratio between the specimens weight and surface area is $220 \mathrm{~g} \mathrm{per} \mathrm{cm}^{2}$. The force of the specimen reduces the thickness of the hide depending on the circulation period.

A meaningful parameter to characterize the tenseness of the hide is defined as the total percentage compressibility value $E$ according to formula 1 .

$E=\frac{I T-T 4}{I T} \times 100$

The value $E$ represents the percentage decrease in thickness after 4 min of pressing time, relative to the initial thickness. In the formula, $I T$ stands for the initial thickness and $T 4$ for the thickness after 4 min of pressing. The smaller the value $E$, the smaller is the compressibility indicating the ratio between positive and negative charges inside the collagen (Zissel and Herfeld 1989).

\section{The $\mathrm{pH}$-values of hide and floats}

The $\mathrm{pH}$-value of the floats from the 20-L trials was directly measured after depressurization and separation with a $\mathrm{pH}$ probe »type 911 « from »Knick Elektronische Messgeräte $\mathrm{GmbH}$ und $\mathrm{Co}$. KG«.

To assess the $\mathrm{pH}$-value of the hides, 3 DIN A5 samples were sammed and the $\mathrm{pH}$ was measured with the $\mathrm{pH}$-probe. An average value including standard deviation was determined.

For the determination of the $\mathrm{pH}$-value in the cross-section, 3 hide samples per trial were cut and wetted with different liquid pH-indicators ordered at Sigma-Aldrich: phenolphthalein (colorless between $\mathrm{pH}-0$ and 8.2), bromothymol blue (change of color from 7 to 8), bromophenol blue (change of color from 3 to 4.6).

The liquid $\mathrm{pH}$-indicators bromothymol blue and bromophenol blue enabled the assessment of the $\mathrm{pH}$-value of aqueous solutions in a pressurized view cell.

\section{Lime- and sulfide-contents of hide and float}

To assess the lime and sulfide content, the calcium and sulfur concentrations were measured by inductively coupled plasma optical emission spectrometry (ICP-OES). The difference in the molecular weight between sulfur and sulfide was neglected. The initial $\mathrm{Ca}$ - and S-contents of the unhaired hides, the conventional delimed hides, and the high- pressure $\mathrm{CO}_{2}$-delimed hides were considered. In addition, the enriched $\mathrm{Ca}-$ and S-contents in the process water were also measured by ICP-OES. For each trial, a double determination was performed.

\section{High-pressure procedure}

\section{Optical assessment of the $\mathrm{pH}$-value}

Distilled water containing bromophenol blue or bromomethyl blue was filled in the view cell. Different amounts of collagen at $\mathrm{pH}-12.5$ were added to investigate the influence of the ratio between water and collagen. Afterwards the cell was pressurized with $5 \mathrm{bar} / \mathrm{min}$. When the color of the indicator changed during the pressurization, a photo was taken and the $\mathrm{pH}$-value assessed. One test series was performed without adding hide to compare the results of $\mathrm{CO}_{2}$-saturated water with available literature data to assess the viability of the procedure. To check whether the collagen or the chemicals inside the collagen influence the color of the $\mathrm{pH}$-indicators by chemical reactions, trials without $\mathrm{CO}_{2}$ pressure were performed.

\section{High-pressure $\mathrm{CO}_{2}$-deliming}

The high-pressure deliming process was performed in a $20-\mathrm{L}$ drum. The DIN A5 hide samples were placed in the rotating basket. The drum was closed and $200 \mathrm{wt} \%$ of water calculated on the hide weight was pumped in. Two hundred weight percent of water is usually used in deliming. Afterwards the reactor was pressurized to the desired pressure of 30 bar. The pressure was kept constant for the defined process time. The considered process times were $25,60,120,180$, and $360 \mathrm{~min}$. The temperature was $30{ }^{\circ} \mathrm{C}$ comparable with conventional deliming and bating. In the end of the process, the drum was depressurized with $1.5 \mathrm{bar} / \mathrm{min}$. At this depressurization kinetics, the hide structure is not damaged, known from previous work. The rotation of the basket was $5 \mathrm{rpm}$ to achieve mechanical movement of the hide. Faster rotations were avoided to protect the surface of the hide samples. After the process, the remaining floats and the treated hide samples were assessed as described in the "Analytics" section. Each experiment was performed two times.

\section{Results and discussion}

\section{Optical pH-assessment of the float containing hide}

\section{Influence of the ratio between water and collagen}

The $\mathrm{pH}$-value of pure water decreases to about 3 by increasing the $\mathrm{CO}_{2}$ pressure to $30 \mathrm{bar}$ (Fig. 1). If the $\mathrm{pH}$-value of collagen 
pressurized with $\mathrm{CO}_{2}$ would also decrease to 3 , acid swelling would irreversibly damage the hide fibers. However, collagen is able to bind protons to the functional amino and carboxy groups ("Collagen" section). The $\mathrm{pH}$-values of aqueous solutions containing collagen pressurized by $\mathrm{CO}_{2}$ are not known. We assessed which $\mathrm{pH}$-values result in a $\mathrm{CO}_{2}$-saturated float containing collagen at $\mathrm{pH}-12.5$ up to 100 bar under variation of the float length. The float length is the ratio between hide and water in weight percentage.

In Fig. 4, the optical pH-assessment by using bromophenol blue as indicator is illustrated in pictures. On the left side are the pictures of the test series without collagen. At ambient conditions, the color of the solution is violet $(\mathrm{pH}>4.6)$. Without increasing the pressure by $\mathrm{CO}_{2}$, the color does not change. By a slight increase in pressure to 0.5 bar, the color changes to red $(4<\mathrm{pH}<$ 4.6). By a further increase in pressure, the color of the solution changes from red to orange to yellow. At 30 bar, the color of the solution is yellow to orange indicating a $\mathrm{pH}$-value slightly above 3 . By increasing the pressure to 100 bar, a pH-value of about 3 is reached.
In the middle of Fig. 4 are the pictures of the test series by using a float length of $4000 \mathrm{wt} \%$. A float length of $4000 \mathrm{wt} \%$ means $10 \mathrm{mg}$ of collagen per $40 \mathrm{~g}$ of water. Compared with the test series performed without collagen, the $\mathrm{pH}$-values are higher. The color changes from violet to red at a pressure of 0.5 bar. However, the transition from red to orange becomes visible at pressures above 15 bar. Without collagen, the transition from red to orange was already observed above 1.5 bar. At 100 bar, the pH-value is between 3 and 3.5. There is no color transition from orange to yellow.

On the right side of Fig. 4 are the results of the test series with a float length of $400 \mathrm{wt} \%$ or $100 \mathrm{mg}$ of collagen per $40 \mathrm{~g}$ of water, respectively. Compared with the previous tests, the $\mathrm{pH}$-values at the different pressure steps are clearly higher. At $400 \mathrm{wt} \%$, the $\mathrm{pH}$-value does not decrease below 4.6 independent from the pressure. At a typical float length of $200 \mathrm{wt} \%$, no color transition was observed.

The optical assessment of the $\mathrm{pH}$-value of pure water pressurized with $\mathrm{CO}_{2}$ is in agreement with data from literature (Meyssami et al. 1992; Mohamed et al. 2011; Peng et al. 2013; Bortoluzzi et al. 2011; Haghi et al. 2017). This indicates
Fig. 4 Pictures of the optical assessment of the $\mathrm{pH}$-values of water and aqueous solutions containing a different amount of collagen in a high-pressure view cell at pressures between $\mathrm{P}_{\mathrm{u}}$ and 100 bar

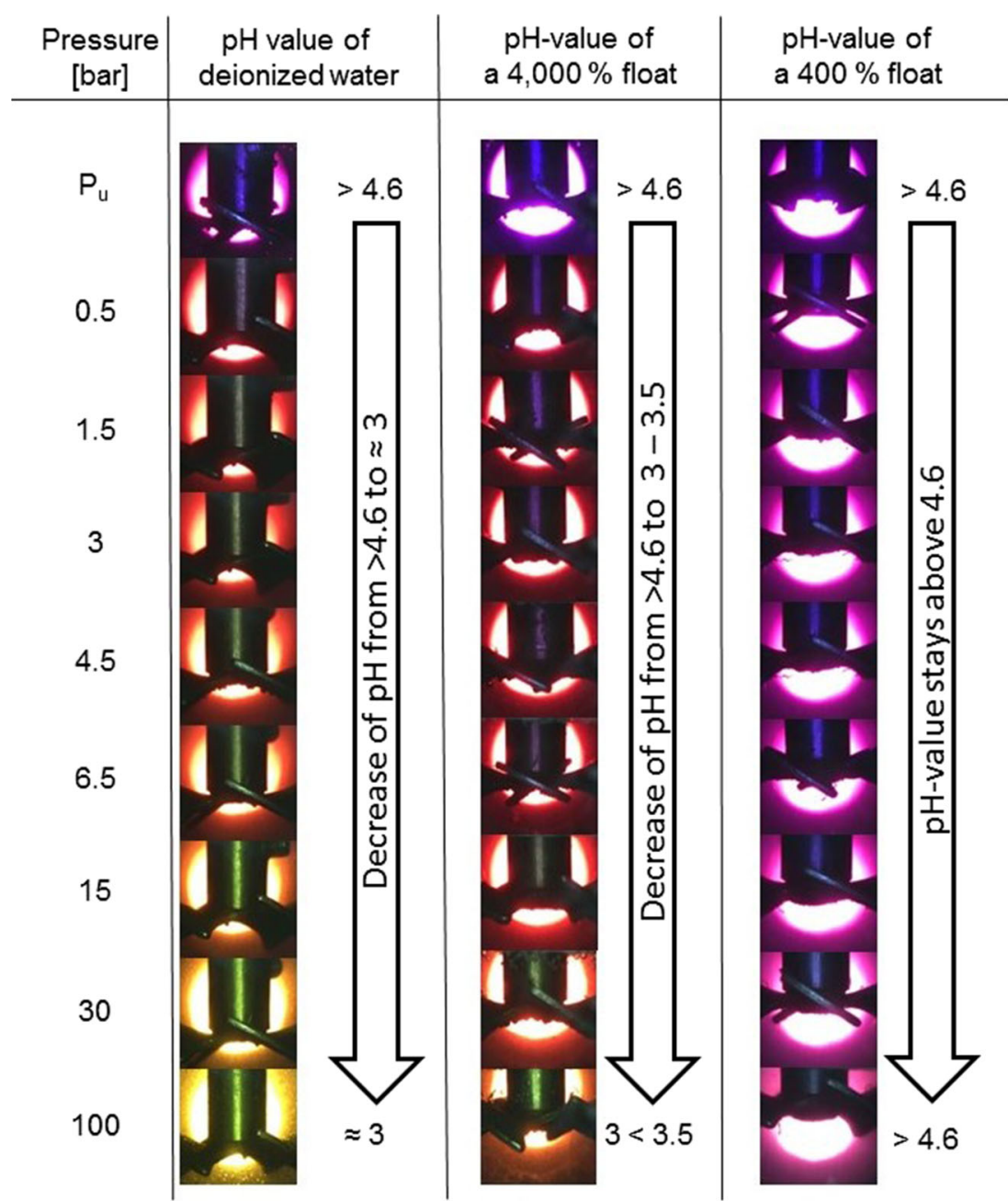


the possibility to visualize the $\mathrm{pH}$-value of water with liquid $\mathrm{pH}$-indicators in a pressurized system. The addition of collagen did not result in a color transition without pressurizing the float. We derive that the collagen and the chemicals inside the collagen do not influence the color of the indicator and conclude that the procedure is feasible.

It has to be noted that the optical assessment of the pHvalue can be connected to different errors (Stippl 2005). The use of $\mathrm{pH}$-probes designed for high-pressure applications enables measurements that are more precise. However, measurements with $\mathrm{pH}$-probes in pressurized systems require very slow pressurizing kinetics to avoid a damage of the probes and are hard to handle (Mohamed et al. 2011). Since the focus of this work is the deliming of animal hides in technical scale where the $\mathrm{pH}$-values of the hide samples are measured with $\mathrm{pH}$-probes ("Influence of $\mathrm{CO}_{2}$ deliming on the $\mathrm{pH}$-value of hide and float" section), we assess the accuracy of the optical assessment as sufficient to estimate how the $\mathrm{pH}$-values of the floats change depending on $\mathrm{CO}_{2}$ pressure and ratio between water and collagen.

The optical $\mathrm{pH}$-indications show that by decreasing the float length, the $\mathrm{pH}$-values decrease at comparable pressures. The reason is the acid binding capacity of collagen. By decreasing the float length, the concentration of functional groups that are able to bind protons increases. Consequently, collagen buffers the $\mathrm{pH}$-value of water pressurized with $\mathrm{CO}_{2}$. However, when the ratio between water and collagen is high, the deviation between the $\mathrm{pH}$-values decreases. This is due to a high surplus of water that increases the availability of dissolved carbon dioxide forming carbonic acid to protonate the functional groups and decrease the $\mathrm{pH}$-value.

No comparable publications that consider the $\mathrm{pH}$-value of aqueous solutions containing collagen pressurized by $\mathrm{CO}_{2}$ are available. However, researchers observed similar trends in pressurized $\mathrm{CO}_{2}$-water systems containing other buffering salts. Andersson et al. investigated the $\mathrm{pH}$-values of ammonium acetate dissolved in water pressurized by $\mathrm{CO}_{2}$. At a constant pressure of $80 \mathrm{bar}$, the $\mathrm{pH}$-values increased from 3.5 to 4.5 by increasing the concentration of the buffering salt from 2 to $30 \mathrm{mM}$ (Andersson et al. 2018). Li et al. showed that in saturated sodium hydrogen carbonate solutions, the $\mathrm{pH}$-value increases at a $\mathrm{CO}_{2}$ pressure of about 90 bar from 4.2 to 6.6 by increasing the salt concentration from 0.01 to $1 \mathrm{~mol} / \mathrm{kg}$ ( $\mathrm{Li}$ et al. 2018).

A float length of $4000 \mathrm{wt} \%$ theoretically allows the reduction of the $\mathrm{pH}$-value directly from 12.5 to about 3 . This enormous $\mathrm{pH}$-drop in one working step could be beneficial for the leather production process. The possible advantage is explained by the fact that before tanning the $\mathrm{pH}$-value has to be reduced to 3 by sulfuric and formic acid (Jia et al. 2016). A substitution of these acids with carbon dioxide would reduce sulfate and formate emissions that are of high concern in the leather industry (Sundar et al. 2002; Galiana-Aleixandre et al. 2011). However, a water consumption of $4000 \mathrm{wt} \%$ is from many points of view not useful. For example, enormous drum volumes and amounts of salt to avoid acid swelling would be needed. Therefore, a typical water consumption of $200 \mathrm{wt} \%$ should be addressed to realize an industrial process.

At a float length of 400 and $200 \mathrm{wt} \%$, bromophenol blue did not show a color transition independent from the applied pressure. Since a water consumption of $200 \mathrm{wt} \%$ and a pressure of 30 bar are useful parameters for an industrial application, we assessed the $\mathrm{pH}$-values at these parameters with bromothymol blue in an additional test series.

\section{Influence of pressure at a constant float length of $200 \mathrm{wt} \%$}

The results of the test series with a float length of $200 \mathrm{wt} \%$ were performed with pressures of 1, 5, and 30 bar. Figures 5 , 6 , and 7 show the photos of the optical assessment of the time depending $\mathrm{pH}$-values of the collagen containing floats with bromothymol blue.

In all test series, the initial color without applying pressure is violet indicating a $\mathrm{pH}>8$. This was expected because the initial $\mathrm{pH}$ of the collagen was 12.5 . Without raising the pressure by $\mathrm{CO}_{2}$, the color of bromothymol blue did not change. By increasing the $\mathrm{CO}_{2}$ pressure, the liquid indicator directly changed the color from violet to yellow at all considered pressures. A yellow color of bromothymol blue indicates that the $\mathrm{pH}$-value decreased below 7. Afterwards the color changed during all experiments to green. The greenish color indicated a $\mathrm{pH}$-value of about 7. The difference between various pressures was that the transition from yellow to green was faster at lower pressures. At $1 \mathrm{bar}$, the transition started after $20 \mathrm{~min}$. By increasing the pressure to $5 \mathrm{bar}$, the transition started after $60 \mathrm{~min}$. At $30 \mathrm{bar}$, it took $7 \mathrm{~h}$ until the transition started. Considering the results after $24 \mathrm{~h}$, the $\mathrm{pH}$-values at all tested pressures were similar independent from the applied pressure.

In the previous test series, we showed that the amount of water and at the same time the availability of dissolved $\mathrm{CO}_{2}$ leads to a decrease of the $\mathrm{pH}$-value. An increased pressure should also increase the solubility and thereby the availability of $\mathrm{CO}_{2}$ molecules. A pressure-induced increase of available $\mathrm{CO}_{2}$ molecules should decrease the $\mathrm{pH}$-value (Bahadori et al. 2009). However, after reaching equilibrium, the color difference and at the same time the difference of the $\mathrm{pH}$-values between the test series is low.

We suggest that the $\mathrm{pH}$-value does not decrease significantly by raising the pressure from 1 to 30 bar because of the buffering effect of the collagen. Collagen has an enormous binding capacity for acids (Brown 2013). For example to saturate the basic groups of 10 tons conventional unhaired hide, $120 \mathrm{~kg}$ of pure sulfuric acid is needed (Covington 2009). Since sulfuric acid is a strong diprotic acid, it derives that about 2.5 thousand mole of oxonium ions are needed to saturate the basic groups of 10 tons unhaired hide. Consequently, 
Fig. 5 Pictures of the optical assessment of the $\mathrm{pH}$-value of a collagen-containing float with a float length of $200 \mathrm{wt} \%$ with bromothymol blue at 1 bar

\begin{tabular}{l|ccccc} 
Time & $\mathrm{P}_{\mathrm{u}} / 0 \mathrm{~min}$ & $1 \mathrm{~min}$ & $20 \mathrm{~min}$ & $60 \mathrm{~min}$ & $24 \mathrm{~h}$ \\
\hline $\begin{array}{l}\text { Bromothymol } \\
\text { blue }\end{array}$ & & & & & \\
\hline $\mathrm{pH}$-value & $>8$ & $<7$ & $\approx 7$ & $\approx 7$ & $\approx 7$
\end{tabular}

in the conventional leather production process, a change of the $\mathrm{pH}$-value and the collagens' reactivity requires high amounts of chemicals (Buljan et al. 2000). At a $\mathrm{CO}_{2}$ pressure of $30 \mathrm{bar}$ and at $30^{\circ} \mathrm{C}$, the $\mathrm{pH}$-value of water decreases to 3 . At $\mathrm{pH}-3$, the oxonium ion concentration is about 0.001 mole per liter. At a float length of $200 \mathrm{wt} \%, 20$ mole of oxonium ions was available to protonate 10 tons of collagen in 20,000 l of water; however, 2.5 thousand is needed. Therefore, it is not surprising that the $\mathrm{pH}$-value of a pressurized aqueous solution differs from an aqueous solution containing collagen as already discussed in the previous section.

It has to be noted that the solubility of $\mathrm{CO}_{2}$ and the dissociation rate are strongly influenced by collagen. Otherwise, the influence on the $\mathrm{pH}$-value would be negligible. The carbon dioxide dissolves in the aqueous solution and dissociates depending on the $\mathrm{pH}$-value partially to $\mathrm{H}^{+}$and $\mathrm{HCO}_{3}{ }^{-}$or $2 \mathrm{H}^{+}$ and $\mathrm{CO}_{3}{ }^{2-}$ (Sontheimer et al. 1980). The $\mathrm{H}^{+}$protonate the reactive groups of the collagen. Thereby, more carbon dioxide dissociates in a solution containing collagen compared with pure water. However, in this complex collagen-water system, we observe that the $\mathrm{pH}$-value is stable at around 7 and does not decrease to 3 as it would happen in water without collagen.

Concurrently to the pressure, the float length influences the $\mathrm{pH}$-value (Fig. 4). However, the float length is a parameter that is hard to change in an industrial deliming process. The surface of swollen unhaired hide at $\mathrm{pH}-12.5$ is sensitive against mechanical influences. A minimum of water is needed to protect the hide. In addition, water is needed to wash out the lime, sulfide, and other dissolved components (Zissel and Herfeld 1989; Covington 2009). A longer float can lead to a further decrease of the $\mathrm{pH}$-value and enable the saving of conventional acids. However, as already discussed in the previous section, a longer float is connected with higher loads and with higher water consumption.

The tests show that at industrial-applicable parameters of 30 bar and a float length of $200 \mathrm{wt} \%$, a stable $\mathrm{pH}$-value of 7 results. We assume that after $24 \mathrm{~h}$ the $\mathrm{pH}$-value does not change anymore. This assumption will be stressed in the "The pH-values of hide and floats" section. A stable $\mathrm{pH}$ value is essential to choose bating enzymes that decompose non-collagen proteins in the following working step ("Conventional deliming" section). At pH-7, possible enzymes that show a high activity are for example papain or casein (Zissel and Herfeld 1989).

To reach a constant $\mathrm{pH}$-value took several hours in the view cell. For an industrial application, the duration for deliming should not exceed 2 h (Deng et al. 2015). However, the process conditions in the view cell differ a lot from the conditions in a rotating drum in which the mechanical action can improve the mass transport. Therefore, trials in a 20 -L autoclave with a rotating basket were performed in technical scale.

\section{$\mathrm{CO}_{2}$-deliming in a $20-\mathrm{L}$ autoclave at 30 bar}

The technical scale experiments were performed as described in the "High-pressure $\mathrm{CO}_{2}$-deliming" section. The experiments enable to analyze hide processed at 30 bar in a rotating basket comparable with a conventional rotating drum. The hide samples and the process floats were analyzed as described in the "Analytics" section.

\section{Influence of $\mathrm{CO}_{2}$-deliming on the hide weight and thickness}

Before $\mathrm{CO}_{2}$ deliming is performed, the unhaired hide at $\mathrm{pH}$ 12.5 is strongly swollen and has a high water content. Depending on the $\mathrm{pH}$-value, the water content and thereby the weight of the hide changes ("Collagen" section).

Figure 8 shows the weight loss in percentage based on the initial weight of the unhaired hide samples depending on the process time after $\mathrm{CO}_{2}$-deliming. The weight loss on average is between 2 and $5 \mathrm{wt} \%$. After the shortest process duration of
Fig. 6 Pictures of the optical assessment of the $\mathrm{pH}$-value of a collagen-containing float with a float length of $200 \mathrm{wt} \%$ with bromothymol blue at 5 bar

\begin{tabular}{l|ccccc} 
Time & $\mathrm{P}_{\mathrm{u}} / 0 \mathrm{~min}$ & $1 \mathrm{~min}$ & $20 \mathrm{~min}$ & $60 \mathrm{~min}$ & $24 \mathrm{~h}$ \\
\hline $\begin{array}{l}\text { Bromothymol } \\
\text { blue }\end{array}$ & & & & &
\end{tabular}


Fig. 7 Pictures of the optical assessment of the $\mathrm{pH}$-value of a collagen-containing float with a float length of $200 \mathrm{wt} \%$ with bromothymol blue at 30 bar

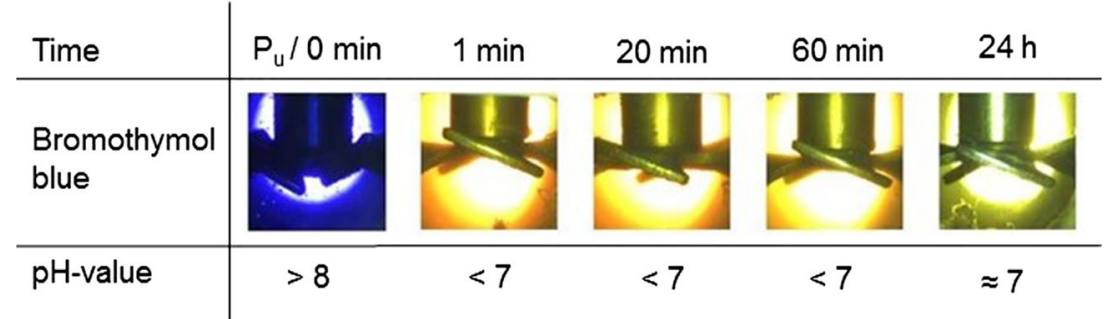

$25 \mathrm{~min}$, the lowest weight loss of $1.2 \mathrm{wt} \%$ with a standard deviation of 1.1 resulted. By increasing the process time to $180 \mathrm{~min}$, the weight loss increases and reaches a maximum of $5 \mathrm{wt} \%$ with a standard deviation of 2.8. At a process time of $360 \mathrm{~min}$, the weight loss was $2.8 \mathrm{wt} \%$ with a standard deviation of 1.6. Except for the shortest process time, all calculated average values are within all standard deviations. Hence, we conclude that increasing the process time above $60 \mathrm{~min}$ has no influence on the weight loss.

Figure 9 shows the water absorption capacity of the collagen depending on the $\mathrm{pH}$-value. The water content of collagen can increase from $60 \mathrm{wt} \%$ (150 g water per $100 \mathrm{~g}$ of dry collagen) from the isoelectric point to about $85 \mathrm{wt} \%$ (650 g water per $100 \mathrm{~g}$ of dry collagen) due to acid or basic swelling.

From the weight loss presented in Fig. 8 in relation to the water absorption capacity shown in Fig. 9, we derive that the $\mathrm{pH}$-values decreased during all $\mathrm{CO}_{2}$-deliming trials. The charges inside the collagen are equalized in the direction of the isoelectric point.

Figure 10 shows the change in thickness of the samples depending on the process time. On average, the thickness of all samples decreased between 8.8 and $13.4 \%$ with standard deviations between 4.1 and 5.2. All average values are within all standard deviations. Compared with the weight loss, the decrease in thickness is in good agreement. When the

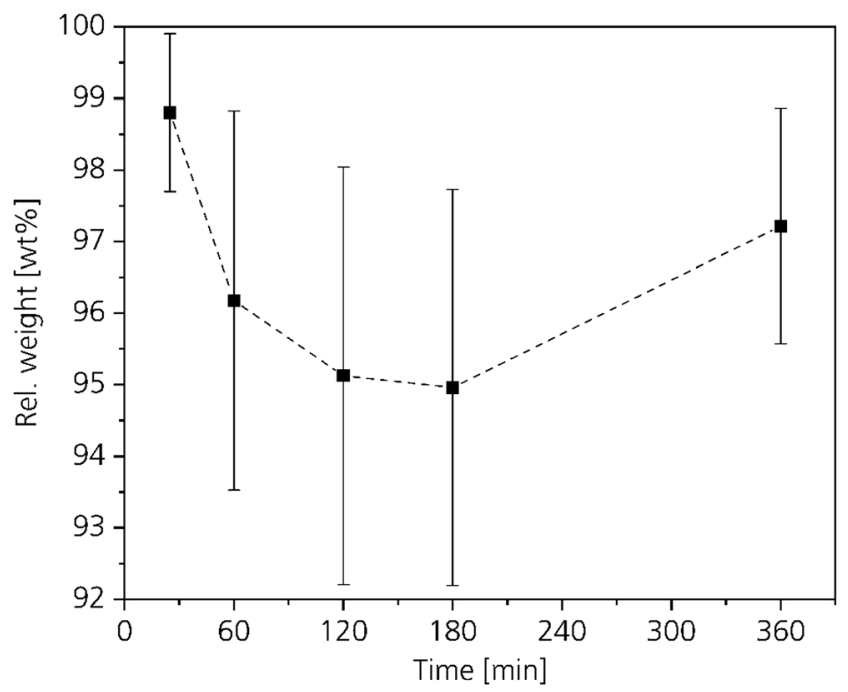

Fig. 8 Influence of $\mathrm{CO}_{2}$-deliming time on the weight loss tenseness is reduced and water and chemicals leave the hide, it is not surprising that also the thickness of the hide decreases.

The results of the weight loss and thickness of the shortest experiment do not perfectly correlate. However, considering the high standard deviations and the natural character of the material, we pay no further attention to this deviation from the other results.

\section{Influence of $\mathrm{CO}_{2}$-deliming on compressibility}

The compressibility value $E$ indicates the tenseness of the collagen fibers. Figure 11 shows the $E$-values of all 30-bar $\mathrm{CO}_{2}$-deliming experiments, of the initial unhaired hide and as reference of a conventional delimed hide. The $E$-value of the unhaired hide is $4.7 \%$ with a standard deviation of 2.4 . The conventional delimed hide has a compressibility value $E$ of $25.5 \%$ with a standard deviation of 2.6. The values show an enormous difference between the compressibility of unhaired hide at $\mathrm{pH}-12.5$ and delimed hide with a $\mathrm{pH}$-value of 9 as described in the "Collagen" section.

The influence of the $\mathrm{pH}$-value on the tenseness relates to the same mechanism as for the weight and thickness. Figure 12 explains the mechanism of the influence of the charges on the orientation of the collagen fibers, schematically. The mass transport in the cross-section of the hide depends on the orientation and tenseness of the collagen fibers influenced by the charges of the reactive groups. Below or above

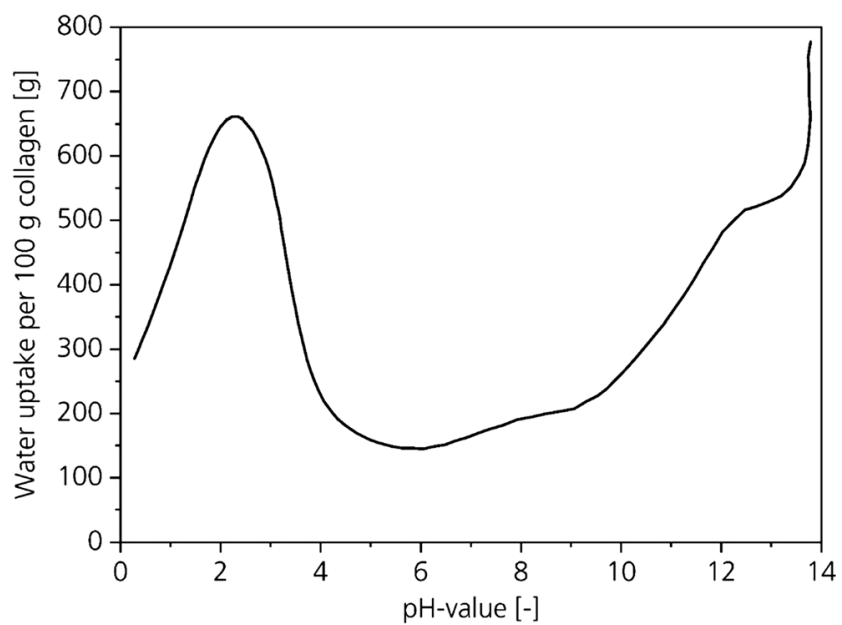

Fig. 9 Water absorption capacity of collagen depending on the $\mathrm{pH}$-value (Covington 2009) 


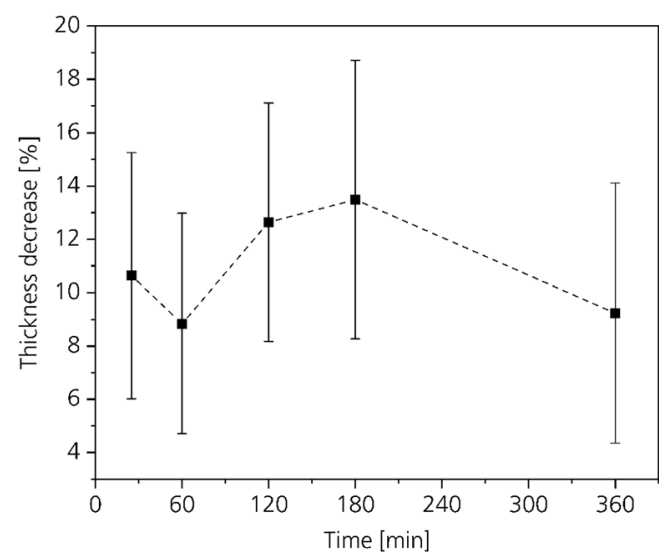

Fig. 10 Influence of the $\mathrm{CO}_{2}$-deliming time on the hide thickness

the isoelectric point, the portion of identical charges in the hide increases. The same charges repel each other. Thereby the fibers tense up, the water absorption capacity increases, the hide swells, and its compressibility decreases. As further from the isoelectric point as slower is the mass transport through structure of the hide and as higher are the $E$-values (Moog 2016; Zissel and Herfeld 1989).

After a process time of $120 \mathrm{~min}$, all compressibility values of the 30 bar $\mathrm{CO}_{2}$-deliming experiments are within or above the standard of the conventional delimed hide. This indicates that the orientation of the collagen fibers and the collagens' charge of the $\mathrm{CO}_{2}$-delimed samples are comparable with conventional delimed hide. After a process time of $60 \mathrm{~min}$, the compressibility is already close to the conventional delimed hide.

The conventional hide was processed in industrial scale in a $12-\mathrm{t}$ batch. The mechanical action in industrial scale is stronger compared with the mechanical action in the 20-L equipment. Thereby, we assume that in industrial scale a process

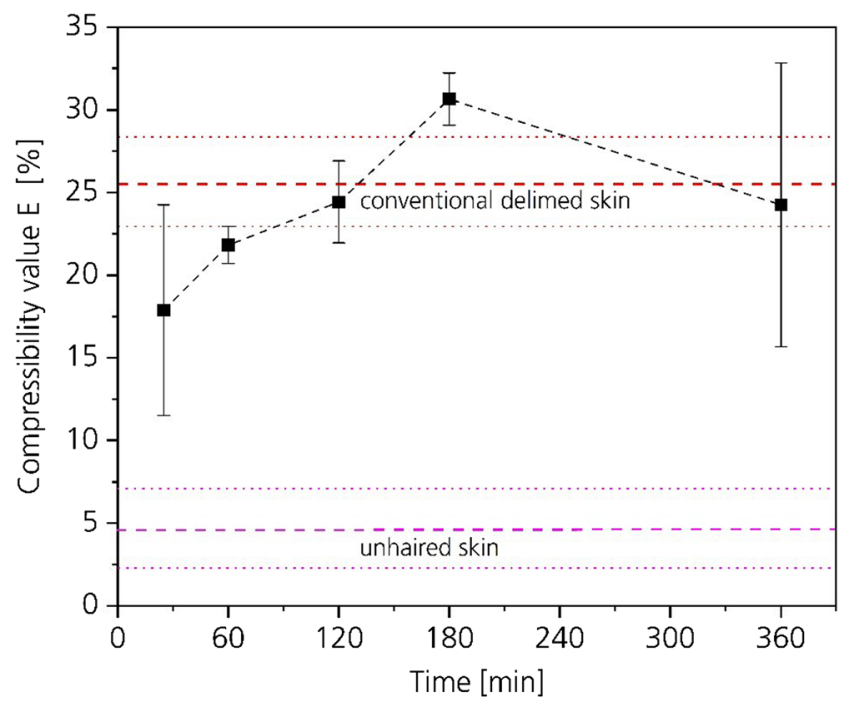

Fig. 11 Influence of $\mathrm{CO}_{2}$-deliming time on the collagens' compressibility time of 60 min would be sufficient to reach an $E$-value comparable with conventional delimed hide.

\section{Influence of $\mathrm{CO}_{2}$ deliming on the $\mathrm{pH}$-value of hide and float}

A stable $\mathrm{pH}$-value is essential for the deliming process. The reason is that in the following bating step, enzymes lose their activity when the $\mathrm{pH}$-value varies. The assessment of the $\mathrm{pH}$ value of the water pressed from the cross-section of all hides resulted in an equal $\mathrm{pH}$-value slightly above 7 , independent from the duration of the process.

Figure 13 shows the $\mathrm{pH}$-values of the hide samples and of the floats of the different time depending experiments assessed by a pH-probe. After a process time of $25 \mathrm{~min}$, the $\mathrm{pH}$-value of the hide was 7.4 with a standard deviation of 0.28 . The float $\mathrm{pH}$ was 6.4 with a standard deviation of 0.06 . By increasing the deliming time to $360 \mathrm{~min}$, the $\mathrm{pH}-$ value of the hide slightly decreases to 7.2 with a standard deviation of 0.1 while the $\mathrm{pH}$-value of the float increases to 6.6 with a standard deviation of 0.05 . Based on the experiments in the view cell with a constant float of $200 \mathrm{wt} \%$ described in the "Influence of pressure at a constant float length of 200 wt \%" section, we assume that the $\mathrm{pH}$-values of the float and the hide meet after reaching equilibrium at a $\mathrm{pH}-$ value of about 7 .

A decrease of the $\mathrm{pH}$-value from 12.5 to 7.4 within the whole cross-section of the hide is already reached within 25 $\min$. The difference between the $\mathrm{pH}$ of the float and the hide after this period is just 1 . We assume that the $\mathrm{pH}$-value after a time of $25 \mathrm{~min}$ is already stable enough to initiate bating, because enzymes that have a high activity between $\mathrm{pH}-6$ and 8 are available (Zissel and Herfeld 1989). Considering that bating takes usually $30 \mathrm{~min}$, a time saving of at least $50 \%$ is possible. Conventional ammonium deliming takes $2 \mathrm{~h}$ (Širvaitytė et al. 2006).

\section{Residual lime and sulfide content}

The most important in the deliming process is that the lime is removed from the hide. Figure 14 shows the $\mathrm{Ca}$ - and $\mathrm{S}$ contents of conventional delimed hides, unhaired hides, and of the $\mathrm{CO}_{2}$-delimed hides at $30 \mathrm{bar}$ based on the dry weight at different process times. Figure 15 shows the $\mathrm{Ca}$ - and $\mathrm{S}$ contents based on the weight of the residual float in grams per kilogram. As already described in the "Lime- and sulfide-contents of hide and float" section, the difference in the molecular weight between sulfur and sulfide is neglected.

The Ca- and S-contents of Figs. 14 and 15 show opposite trends. The contents in the collagen decrease while the contents in the float increase by increasing the time. This is not surprising, because a decrease of the calcium and sulfide contents in the hide have to be linked to an increase of calcium and sulfide in the float. 
Fig. 12 Schematic mechanism of the influence of the charges on the orientation of the collagen fibers

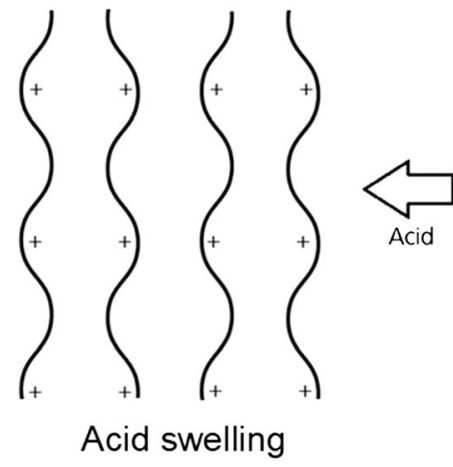

Acid swelling

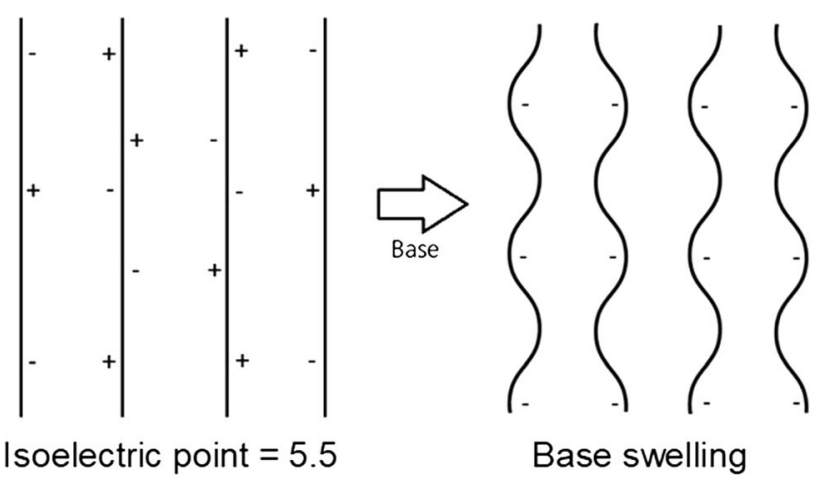

The initial Ca-content of the unhaired hide is $7.8 \mathrm{~g} / \mathrm{kg}$ with a standard deviation of 0.69 . The Ca-content of the conventional delimed hide is with $4.1 \mathrm{~g} / \mathrm{kg}$ and a standard deviation of 0.05 about $50 \mathrm{wt} \%$ lower compared with the initial Ca-content.

After a process time of $25 \mathrm{~min}$, the calcium content is with $5.25 \mathrm{~g} / \mathrm{kg}$ about $20 \mathrm{wt} \%$ higher compared with the conventional delimed hide. However, by increasing the process time, the Ca-content in the hide decreases below the value of the conventional delimed hide already after $60 \mathrm{~min}$. A further increase of the process time results in a decrease of the Cacontent. After $180 \mathrm{~min}$, a nearly two times lower Ca-content compared with conventional delimed hide results. By decreasing the Ca-contents in the hide, the Ca-contents in the float increase from 0.4 to $0.8 \mathrm{~g} / \mathrm{kg}$ by increasing the process time.

The reached Ca-contents confirm that a duration of $60 \mathrm{~min}$ for $\mathrm{CO}_{2}$-deliming at 30 bar including bating is sufficient to reach comparable results with a conventional deliming process of $2 \mathrm{~h}$. It can be assumed that the residual $\mathrm{Ca}$ is associated to the anionic carboxy groups and would even remain inside the hide after longer deliming durations.

The initial sulfide content is $7.1 \mathrm{~g} / \mathrm{kg}$ with a standard deviation of 0.4 . The residual content of the conventional delimed

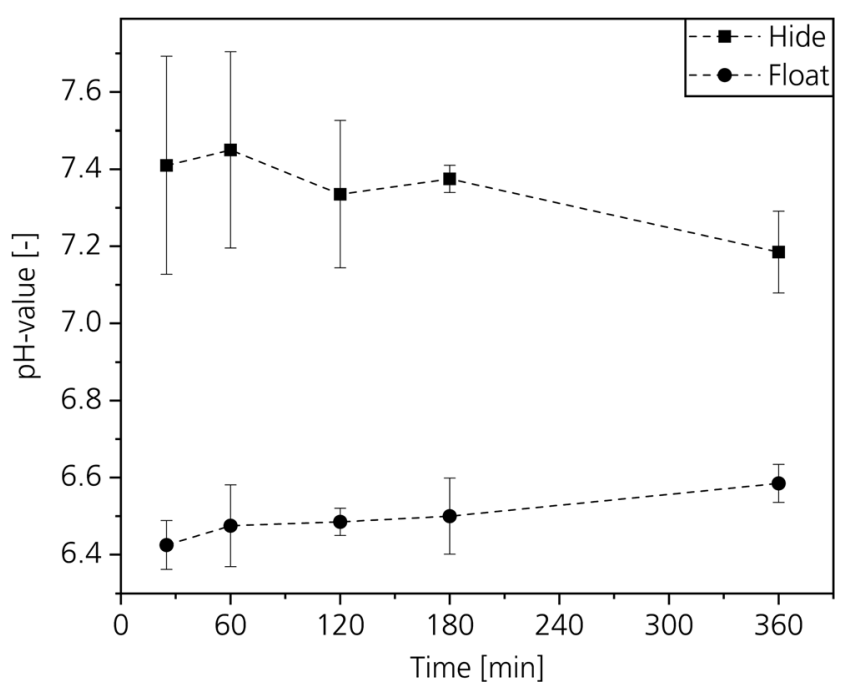

Fig. 13 Influence of the process time on the $\mathrm{pH}$-values of collagen and float hide is $6.1 \mathrm{~g} / \mathrm{kg}$ with a standard deviation of 0.01 . In the $\mathrm{CO}_{2}$ deliming process, the sulfide contents are between 4.5 and 5 $\mathrm{g} / \mathrm{kg}$ independent from the process time. This indicates that an improved mass transport in the high-pressure process enables a fast sulfide removing. After $25 \mathrm{~min}$, the influence on the decrease of sulfide is negligible. This is caused by the fact that some amino acids contain sulfur that is not washed out.

Depending on the $\mathrm{pH}$-value, the remaining sulfides can form dangerous hydrogen sulfide. The concentration of hydrogen sulfide increases at $\mathrm{pH}$-values below 9. To avoid the formation of hydrogen sulfide, oxidizing agents as hydrogen peroxide can be added (Deng et al. 2015). However, a tanning drum designed for high-pressure applications is sealed against the atmosphere. Therefore, all formed hydrogen sulfide remains in the process and does not get in contact with workers. Because the majority of the gas mixture within the process is non-flammable $\mathrm{CO}_{2}$, no explosive gas mixtures are formed. The portion of oxygen in the process chamber is negligible. During the depressurization, formed hydrogen sulfide can be separated from the gas stream without adding oxidizing agents that contaminate the wastewater. Possibly, the formed hydrogen sulfide can be used as feedstock for the production of

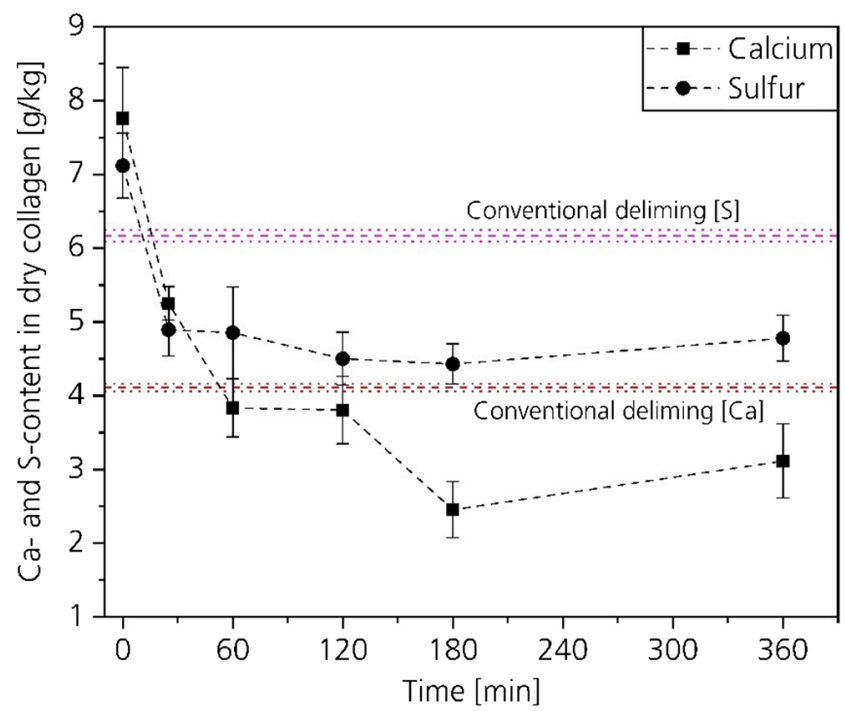

Fig. 14 Residual Ca- and S-contents in dry collagen 


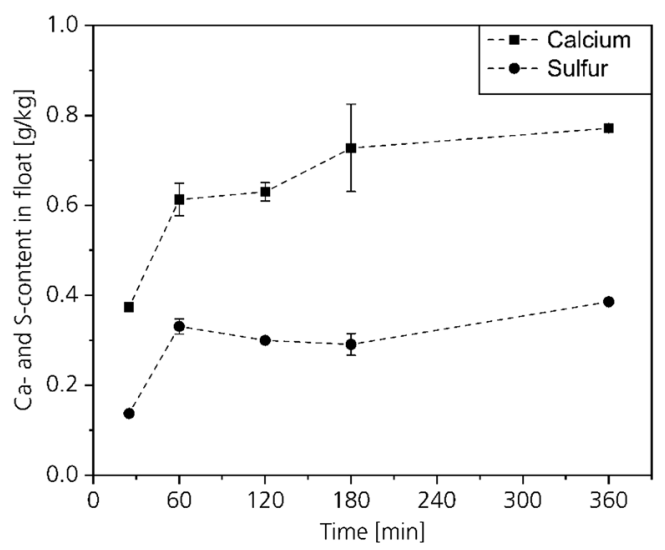

Fig. 15 Calcium and sulfur contents in the residual float

sodium sulfide. Sodium sulfide is used for unhairing in the leather production chain (Quadery et al. 2014).

\section{Conclusion}

We successfully performed salt-free $\mathrm{CO}_{2}$-deliming of unhaired hide in a pressurized autoclave at 30 bar. The tenseness of the $\mathrm{CO}_{2}$-delimed collagen fibers with pressurized $\mathrm{CO}_{2}$ is comparable with the tenseness of conventional delimed hide after a treatment of $60 \mathrm{~min}$. A fast reduction of the tenseness is essential for an accelerated processing because the mass transport of water, lime, and sulfide increases by decreasing the tenseness. A residual Ca-content comparable with conventional delimed hide of about $0.4 \mathrm{~g} / \mathrm{kg}$ based on the dry collagen weight was also reached within $1 \mathrm{~h}$. The results show that a salt-free deliming by saving $50 \%$ of process time can be realized.

By the optical assessment of the $\mathrm{pH}$-value in the view cell, we showed that an increased amount of water results in a decreased $\mathrm{pH}$-value at the same pressure. This is explained by the higher availability of dissolved $\mathrm{CO}_{2}$ at a higher offer of water forming carbonic acid. However, because an unacceptable water consumption is needed to achieve a significant $\mathrm{pH}$-decrease, we focused on a typical float length of $200 \mathrm{wt} \%$.

Without buffering salts, the $\mathrm{pH}$-value decreases from 12.5 to about 7 after reaching equilibrium at a float length of $200 \mathrm{wt} \%$ and pressures up to $30 \mathrm{bar}$. After $25 \mathrm{~min}$, the difference in the $\mathrm{pH}$-values between the float and the hide is 1 . We assume that the $\mathrm{pH}$-value after $25 \mathrm{~min}$ is stable enough to initiate bating. Enzymes that have a high activity between 6 and 8 to decompose non-collagen proteins are available. However, since we focused only on deliming, the influence of different bating enzymes on the leather properties operating at $\mathrm{pH}$-values between 6 and 8 has to be assessed in additional work.

It has to be noted that in an industrial application, the formation of the dangerous hydrogen sulfide is promoted at the lower $\mathrm{pH}$-value that results at 30 bar compared with conventional deliming. However, because the reaction happens in a sealed autoclave without the presence of oxygen, no additional chemicals as hydrogen peroxide have to be used. Hydrogen sulfide can be separated from the gas stream, transformed to sodium sulfide, and reused for unhairing.

In sum, the salt-free $\mathrm{CO}_{2}$-deliming enables an accelerated deliming of animal hides without any ammonium nitrogen emission. In combination with the $\mathrm{CO}_{2}$-intensified low chromium and sulfate emission tanning, $\mathrm{CO}_{2}$-deliming has high potential to enable environmental friendly industrial beamhouse and tanning operations.

Funding Information Open Access funding provided by Projekt DEAL.

Open Access This article is licensed under a Creative Commons Attribution 4.0 International License, which permits use, sharing, adaptation, distribution and reproduction in any medium or format, as long as you give appropriate credit to the original author(s) and the source, provide a link to the Creative Commons licence, and indicate if changes were made. The images or other third party material in this article are included in the article's Creative Commons licence, unless indicated otherwise in a credit line to the material. If material is not included in the article's Creative Commons licence and your intended use is not permitted by statutory regulation or exceeds the permitted use, you will need to obtain permission directly from the copyright holder. To view a copy of this licence, visit http://creativecommons.org/licenses/by/4.0/.

\section{References}

Andersson M, Rodriguez-Meizoso I, Turner C, Hjort K, Klintberg L (2018) Dynamic $\mathrm{pH}$ determination at high pressure of aqueous additive mixtures in contact with dense $\mathrm{CO} 2$. The Journal of Supercritical Fluids 136:95-101. https://doi.org/10.1016/j.supflu. 2018.02.012

Bahadori A, Vuthaluru HB, Mokhatab S (2009) New correlations predict aqueous solubility and density of carbon dioxide. International Journal of Greenhouse Gas Control 3(4):474-480. https://doi.org/ 10.1016/j.ijggc.2009.01.003

Black M, Canova M, Rydin S, Scalet BM, Roudier S, Sancho L.D. (2013) JRC RR - Best available techniques (BAT) reference document for the tanning of hides and skins

Bortoluzzi D, Cinquemani C, Torresani E, Spilimbergo S (2011) Pressure-induced $\mathrm{pH}$ changes in aqueous solutions - on-line measurement and semi-empirical modelling approach. The Journal of Supercritical Fluids 56(1):6-13. https://doi.org/10.1016/j.supflu. 2010.11.007

Brown EM (2013) Development and utilization of a bovine type I collagen microfibril model. International journal of biological macromolecules 53:20-25. https://doi.org/10.1016/j.ijbiomac.2012.10.029

Buljan J (2000) The scope for decreasing pollution load in leather processing

Buljan J, Reich G, Ludvijk J (2000) Mass balance in leather processing

Chuang MH, Johannsen M (eds) (2009) Characterization of pH in aqueous CO2-systems

Cotance (2012) Sozial und Umweltbericht. Die Europäische Lederindustrie

Covington AD (2009) Tanning chemistry. RSC Publishing, Cambridge, The science of leather 
Deng W, Chen D, Huang M, Hu J, Chen L (2015) Carbon dioxide deliming in leather production: a literature review. Journal of Cleaner Production 87:26-38. https://doi.org/10.1016/j.jclepro. 2014.09.066

Duan Z, Sun R (2003) An improved model calculating CO2 solubility in pure water and aqueous $\mathrm{NaCl}$ solutions from 273 to $533 \mathrm{~K}$ and from 0 to 2000 bar. Chemical Geology 193:257-271

Faber K, Herfeld H (1990) Gerbmittel, Gerbung, Nachgerbung. Mit 30 Tabellen, 2. Aufl. Bibliothek des Leders, / Hans Herfeld Hrsg. ; 3. Umschau-Verl., Frankfurt am Main

Flowers KB (2002) Accelerated carbon dioxide deliming of cattle hides and sheepskins. University, Rhodes

Galiana-Aleixandre M-V, Mendoza-Roca J-A, Bes-Piá A (2011) Reducing sulfates concentration in the tannery effluent by applying pollution prevention techniques and nanofiltration. Journal of Cleaner Production 19(1):91-98. https://doi.org/10.1016/j.jclepro. 2010.09.006

Guttenberg HG (1994) Verfahren zur Herstellung von Leder aus Tierhäuten (EP0624654A2)

Haghi RK, Chapoy A, Peirera LMC, Yang J, Tohidi B (2017) pH of CO2 saturated water and $\mathrm{CO} 2$ saturated brines: experimental measurements and modelling. International Journal of Greenhouse Gas Control 66:190-203. https://doi.org/10.1016/j.ijggc.2017.10.001

Heidemann E (1993) Fundamentals of leather manufacture. Roether, Darmstadt

Hu J, Deng W (2016) Application of supercritical carbon dioxide for leather processing. Journal of Cleaner Production 113:931-946. https://doi.org/10.1016/j.jclepro.2015.10.104

Jia L, Ma J, Gao D, Lyu B, Zhang J (2016) Application of an amphoteric polymer for leather pickling to obtain a less total dissolved solids residual process. Journal of Cleaner Production 139:788-795. https://doi.org/10.1016/j.jclepro.2016.08.097

Joseph K, Nithya N (2009) Material flows in the life cycle of leather. Journal of Cleaner Production 17(7):676-682. https://doi.org/10. 1016/j.jclepro.2008.11.018

Li X, Peng C, Crawshaw JP, Maitland GC, Trusler JM (2018) The pH of $\mathrm{CO} 2$-saturated aqueous $\mathrm{NaCl}$ and $\mathrm{NaHCO} 3$ solutions at temperatures between $308 \mathrm{~K}$ and $373 \mathrm{~K}$ at pressures up to $15 \mathrm{MPa}$. Fluid Phase Equilibria(458):253-263

Lofrano G, Meriç S, Zengin GE, Orhon D (2013) Chemical and biological treatment technologies for leather tannery chemicals and wastewaters: a review. The Science of the total environment 461-462: 265-281. https://doi.org/10.1016/j.scitotenv.2013.05.004

Meregallo E, Becalli M (1990) Process for deliming hides in the tanning industry and apparatus for carrying out said process (EP0439108B)

Meyssami B, Balaban MO, Teixeira AA (1992) Prediction of the $\mathrm{pH}$ in model systems pressurized with carbon dioxide. Biotechnol. Prog. 8:149-154

Mohamed MF, Nor AM, Suhor MF, Singer M, Choi YS, Nesic S (2011) Water chemistry for corrosion prediction in high pressure $\mathrm{CO} 2$ environments

Moog GE (2016) Der Gerber. Professionelle Lederherstellung, 2., aktualisierte Auflage. Ulmer, Stuttgart (Hohenheim)

Onem E, Renner M, Prokein M (2018) Green separation and characterization of fatty acids from solid wastes of leather industry in supercritical fluid $\mathrm{CO} 2$. Environmental science and pollution research international 25(22):22213-22223. https://doi.org/10.1007/s11356$018-2350-2$
Paul RG, Bailey AJ (2003) Chemical stabilisation of collagen as a biomimetic. TheScientificWorldJournal 3:138-155. https://doi.org/10. 1100/tsw.2003.13

Peng C, Crawshaw JP, Maitland GC, Martin Trusler JP, Vega-Maza D (2013) The $\mathrm{pH}$ of $\mathrm{CO} 2$-saturated water at temperatures between $308 \mathrm{~K}$ and $423 \mathrm{~K}$ at pressures up to $15 \mathrm{MPa}$. The Journal of Supercritical Fluids 82:129-137. https://oi.org/10.1016/j.supflu. 2013.07.001

Prokein M, Renner M, Weidner E, Heinen T (2017) Low-chromium- and low-sulphate emission leather tanning intensified by compressed carbon dioxide. Clean Techn Environ Policy 19(10):2455-2465. https://doi.org/10.1007/s10098-017-1442-x

Quadery AH, Uddin T, Azad AK, Chowdhury MJ, Deb A. K., Hassan N (2014) Development of hair-save unhairing method using organic thio compounds in pre-tanning stages of leather production. International Journal of Scientific \& Engineering Research 12(5): 376-382

Reich G, Taeger T (2009) Chemikalien für die Lederherstellung. Vom Kollagen tierischer Häute zum Werkstoff Leder. Chem. Unserer Zeit 43(1):28-36. https://doi.org/10.1002/ciuz.200900473

Renner M (2015) Verfahrensentwicklung zur abwasserfreien Gerbung tierischer Häute unter dem Einfluss verdichteten Kohlendioxids. Dissertation, Karl-Maria Laufen Nachf. Wilhelm R. Kurze

Renner M, Weidner E, Brandin G (2009) High-pressure carbon dioxide tanning. Chemical Engineering Research and Design 87(7):987996. https://doi.org/10.1016/j.cherd.2008.12.013

Renner M, Weidner E, Jochems B, Geihsler H (2012) Free of water tanning using $\mathrm{CO} 2$ as process additive - an overview on the process development. The Journal of Supercritical Fluids 66:291-296. https://doi.org/10.1016/j.supflu.2012.01.007

Sathish M, Madhan B, Sreeram KJ, Raghava Rao J, Nair BU (2016) Alternative carrier medium for sustainable leather manufacturing a review and perspective. Journal of Cleaner Production 112:49-58. https://doi.org/10.1016/j.jclepro.2015.06.118

Širvaityte J, Valeika V, Beleška K, Valeikienè V (2006) Bating of pelts after deliming with peracetic acid. Proceedings of the Estonian Academy of Sciences. Chemistry(55):93-100

Sontheimer H, Spindler P, Rohmann U (1980) Wasserchemie für Ingenieure. ZfGW-Verlag GmbH, Framkfurt a.M

Stippl M (2005) Optical in-situ measurement of the $\mathrm{pH}$-value during high pressure treatment of fluid food. Technische Universität, München

Sundar VJ, Raghava Rao J, Muralidharan C (2002) Cleaner chrome tanning - emerging options. Journal of Cleaner Production(10):69-74

Wang Y, Zeng Y, Chai X, Liao X, He Q, Shi B (2012) Ammonia nitrogen in tannery wastewater: distribution, origin and prevention. journal of the american leather chemists association 107:40-50

Weidner E (2018) Impregnation via supercritical CO2 -what we know and what we need to know. The Journal of Supercritical Fluids 134: 220-227. https://doi.org/10.1016/j.supflu.2017.12.024

Zissel A, Herfeld H (1989) Arbeiten der Wasserwerkstatt bei der Lederherstellung. Bibliothek des Leders, / Hans Herfeld Hrsg. ; 2. Umschau-Verl., Frankfurt am Main

Publisher's note Springer Nature remains neutral with regard to jurisdictional claims in published maps and institutional affiliations. 